\title{
IMPELEMENTASI ALGORITMA PROFILE MATCHING DALAM PEMBERIAN BONUS AKHIR TAHUN KARYAWAN
}

\author{
Fakhrul Arifqi, Joko Sutrisno \\ Program Studi Sistem Informasi, Universitas Budi Luhur \\ Jl. Ciledug Raya, Jakarta Selatan \\ fakhrularifqi94@gmail.com, joko.sutrisno@budilhur.ac.id
}

\begin{abstract}
To support the performance and motivate the spirit of employees in the work then it is necessary to reward a certain amount of money as a form of appreciation to the employees of the yearend bonus recipients. As for the problems that occur during this there is a subjective assessment of the next side assessment to a person employee so that the employee whose target scale is achieved does not get the final bonus. In this research using the Profile Matching method in resolving the problem, the Profile Matching method is implemented into a decision support system. So the results of this research is an application that can provide output in the form of each employee's alignment so that decisionmakers can consider and make decisions about who the employees are selected to get the year-end bonus.
\end{abstract}

Keywords - Assessment, Profile Matching, Employees, Decisions.

\begin{abstract}
Untuk menunjang kinerja dan memotivasi semangat karyawan dalam bekerja maka diperlukan sebuah penghargaan berupa nominal uang dengan jumlah tertentu sebagai bentuk apresiasi kepada karyawan penerima bonus akhir tahun. Adapun permasalahan yang terjadi selama ini adanya penilaian yang bersifat subyektif yaitu penilaian berpihak sebelah kepada seseorang karyawan sehingga karyawan yang target penjualanya tercapai tidak mendapatkan bonus akhir. Pada penelitian ini menggunakan metode Profile Matching didalam menyelesaikan permasalahan tersebut, metode Profile Matching diimplementasikan kedalam sebuah sistem pendukung keputusan. Sehingga hasil penelitian ini adalah sebuah aplikasi yang mampu memberikan keluaran berupa perangkingan masing-masing karyawan sehingga pihak pengambil keputusan dapat mempertimbangkan dan mengambil keputusan mengenai siapa karyawan yang terpilih untuk mendapatkan bonus akhir tahun.
\end{abstract} Kata kunci - Penilaian, Profile Matching, Karyawan, Keputusan.

\section{PENDAHULUAN}

Pemberian Bonus Akhir tahun kerap dilakukan oleh beberapa perusahaan-perusahaan untuk memacu semangat kerja para karyawan. Akan tetapi pada pelaksanaan penilaian karyawan terjadi penilaian yang tidak adil dan menguntungkan pihak-pihak tertentu. Pemanfaatan teknologi informasi sekarang ini digunakan untuk membantu para pihak pengambil keputusan. Salah satu diantaranya adalah sistem pendukung keputusan. Dalam pengertian khusus, sebuah Sistem pendukung keputusan dapat diartikan dalam sebuah sistem atau aplikasi yang mampu mendukung kegiatan kerja dari seorang manager maupun kelompok manager pada proses pemecahan masalah yang berbentuk semi terstruktur [1].Pada sebuah sistem pendukung keputusan tersebut terdapat beberapa metode atau algoritma salah satu diantaranya yakni metode Profile Matching. Metode Profile matching yakni sebuah bentuk pengambilan suatu keputusan dengan mengasumsikan terdapat beberapa tingkat variabel prediktor yang ideal serta harus dapat dipenuhi oleh subyek yang akan diteliti, tetapi bukan tingkat minimal yang wajib dipenuhi atau dilewati [2]. Dimana nantinya metode Profile Matcing tersebut diimplementasikan kedalam aplikasi untuk membantu pengambilan keputusan dalam memilih karyawan yang layak mendapatkan bonus akhir tahun, sehingga pihak pengambil keputusan dapat mengambil keputusan berdasarkan perangkingan nilai dari aplikasi tersebut. Penelitian yang memanfaatkan algoritma profile matching banyak digunakan oleh peneliti-peneliti salah satunya adalah Haryani dan Dina Fitriani yang berjudul Sistem Pendukung Keputusan Penentuan Karyawan Terbaik Pada Collection PT.Panin Bank Menggunakan Metode Profile Matching pada penelitian tersebut menggunakan kriteria yaitu Perfomance, Produktivitas dan Absensi pada departemen collection personal loan. pada penelitiannya fokus aspek produktivitas serta kualitas dengan kondisi dimana total jumlah para kandidat karyawan terbaik yang akan diambil lebih banyak jumlahnya dari posisi predikat calon karyawan terbaik. hasil penelitiannya berupa aplikasi sistem pendukung keputusan yang dapat memberikan bobot kompetensi tertinggi yang menjadi karyawan terbaik [3]. sedangkan pada penelitian ini menggunakan aspek kinerja dan personality dan bentuk keluaran aplikasi berupa perangkingan. Pemanfaatan algoritma profile matching untuk perekrutan karyawan dilakukan oleh Mulis Sulistiyono dan Bernadhed yang berjudul Implementasi Sistem Pendukung Keputusan Seleksi 
Penerimaan Karyawan Baru Dengan Metode Profile Matching pada penelitiannya menggunkaan 3 buah kriteria diantaranya adalah Intelektual, Kepribadian dan Sikap Kerja dan tiap-tiap kriteria dibagi menjadi Core Factor dan Secondary Factor. pada penelitian ini nilai yang terbesar adalah nilai yang dapat mempengaruhi seleksi calon karyawan. Adapun kriteria yang digunakan yakni kognitif (K1) nilai 40\%, kepribadian (K2) nilai $30 \%$ sert sikap kerja dengan nilai $30 \%$. Berdasarkan keluaran dari penelitiannya menunjukan nilai 4,78 yakni nilai yang terbesar dan rangking satu. Dan untuk rangking dua sampai empat adalah nilai 4,65 , 4,63, serta 4,60 [4]. Sedangkan pada penelitian ini menggunakan aspek kinerja dengan bobot $60 \%$ dan personality $40 \%$ dan penilaian menggunakan skala 1-4. Sedangkan penelitian pemberian bonus juga telah dilakukan oleh Adin Setiawan, Sutardi dan LM. Tajidun yang berjudul SPK Penilaian dan Pemberian Bonus Salesman Pada PT Matakar Kendari dengan menggunakan Metode Profile Matching. pada penelitiannya menggunakan kriteria Posisi/Jabatan, Target dan Perilaku. pada penelitiannya masing-masing karyawan akan mendapatkan bonus sesuai dengan urutan perangkingan. sedangkan pada penelitian ini yang berhak mendapatkan bonus akhir tahun adalah satu orang karyawan dengan peringkat rangking 1 [5] sedangkan pada penelitian ini menggunakan kriteria Kinerja dengan bobot $60 \%$ dan Personality $40 \%$ dan hasil keluaran aplikasi berupa perangkingan dan grafik nilai masing-masing karyawan.

\section{A. Sistem Pendukung Keputusan}

Sistem Pendukung Keputusan atau Decision Support System (DSS) adalah sistem yang mampu membantu para manajer serta pihak pengambil keputusan pada saat akan mengambil keputusan pada suatu keadaan yang semiterstruktur [6]. Adapun tujuan dari Sistem Pendukung Keputusan atau Decision Support System (DSS) yakni sebagai berikut [7] Membantu pihak-pihak yang akan mengambil sebuah keputusan yang berbentuk semiterstruktur, dapat memberikan pertimbangan-pertimbangan pada level manajer dalam mengambil sebuah keputusan namum tidak ada tujuan untuk menggantikan fungsi dan persan seorang manajer, dapat meningkatkan efektivitas pada saat pengambilan sebuah keputusan oleh manajer, dapat meningkatkan kecepatan pada saat proses komputasi. Dengan komputasi maka pihak pengambil keputusan dengan cepat serta biaya yang rendah dapat mengambil suatu keputusan, dapat meningkatkan produktivitas para manajer. Kemudian dapat meningkatkan produktivitas dari staf-staf yang lainnya dengan dukungan komputerisasi.

\section{B. Profile Matching}

profile matching jika diartikan secara garis besar adalah suatu proses perbandingan antara nilai kompetensi individu kedalam nilai kompetensi jabatan sehingga diketahui sebuah perbedaan kompetensinya kadang disebut juga dengan GAP, semakin kecil nilai sebuah GAP yang dihasilkan maka nilai dari bobot itu semakin besar hal ini berarti karyawan tersebut memiliki peluang yang lebih besar untuk menempati posisi atau sebagai kandidat karyawan tertentu [8].

Adapun proses didalam Profile Matching adalah sebagai berikut [9] :

\section{Pemetaan Gap Kompetensi}

Gap komptensi dimaksudkan untuk mencari perbedaan diantara profil kriteria dengan profil karyawan. Untuk mencari Gap Kompetensi dapat menggunakan rumus (1).

GAP = nilai karyawan - nilai standar $($ Minimum $)$

\section{Pembobotan Gap}

Setelah nilai Gap pada masing-masing karyawan diperoleh, maka langkah selanjutnya adalah memberikan bobot nilai Gap berdasarkan tabel 1 .

\begin{tabular}{|c|c|c|c|}
\hline No & Selisih & $\begin{array}{l}\text { Bobot } \\
\text { Nilai }\end{array}$ & Keterangan \\
\hline 1 & 0 & 5 & 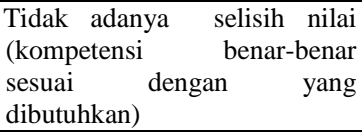 \\
\hline 2 & 1 & 4,5 & 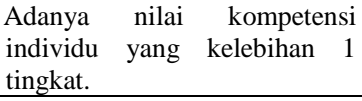 \\
\hline 3 & -1 & 4 & $\begin{array}{lcc}\text { Adanya } & \text { nilai } & \text { kompetensi } \\
\text { individu yang } & \text { kekurangan } 1 \\
\text { tingkat } & & \end{array}$ \\
\hline 4 & 2 & 3,5 & $\begin{array}{lcc}\text { Adanya } & \text { nilai } & \text { kompetensi } \\
\text { individu } & \text { yang } & \text { kelebihan } 2 \\
\text { tingkat } & & \\
\end{array}$ \\
\hline 5 & -2 & 3 & $\begin{array}{l}\text { Adanya } \text { nilai } \\
\text { individu yang } \\
\text { tingkat }\end{array}$ \\
\hline 6 & 3 & 2,5 & \begin{tabular}{lcc} 
Adanya & nilai & \multicolumn{2}{c}{ kompetensi } \\
individu & yang & kelebihan 3 \\
tingkat & & \\
\end{tabular} \\
\hline 7 & -3 & 2 & $\begin{array}{lcc}\text { Adanya } & \text { nilai } & \text { kompetensi } \\
\text { individu yang } & \text { kekurangan } 3 \\
\text { tingkat } & & \\
\end{array}$ \\
\hline 8 & 4 & 1,5 & \begin{tabular}{lccc} 
Adanya & nilai & \multicolumn{2}{c}{ kompetensi } \\
individu & yang & kelebihan & 4 \\
tingkat & & & \\
\end{tabular} \\
\hline 9 & -4 & 1 & $\begin{array}{lcc}\text { Adanya } & \text { nilai } & \text { kompetensi } \\
\text { individu yang } & \text { kekurangan } 4 \\
\text { tingkat } & & \end{array}$ \\
\hline
\end{tabular}

Setelah nilai Gap masing-masing karyawan maka langkah berikutnya adalah mengelompokan kriteria menjadi 2 kelompok, yaitu kelompok Core Factor dan kelompok Secondary Factor.

Pada perhitungan core factor ditunjukan pada rumus (2)

$$
\mathrm{NCF}=\frac{\sum \mathrm{NC}}{\sum \mathrm{IC}}
$$


Penjelasan :

$\mathrm{NCF}=$ nilai rata-rata dari core factor

$\mathrm{NC}=$ nilai total dari core factor

IC = nilai keseluruhan core factor

Sedangkan untuk perhitungan Secondary factor ditunjukan pada rumus (3)

$\mathrm{NSF}=\frac{\sum \mathrm{NS}}{\sum \mathrm{IS}}$

Penjelasan :

$\mathrm{NSF}=$ nilai rata-rata dari secondary factor

$\mathrm{NS}=$ nilai total dari secondary factor

IS = nilai keseluruhan dari secondary factor

Menghitung Total Nilai Kriteria

Setelah mendapatkan nilai kriteria dari masing-masing kelompok Core Factor dan nilai dari kelompok Secondary Factor, maka tahap selanjutnya adalah menghitung total nilai yang diambil dari persentase core factor serta presentasi secondary factor. Adapun rumus atau formula dapat dilihat pada formula (4)

$\mathrm{N}=(\mathrm{x}) \% \mathrm{NCF}+(\mathrm{x}) \% \mathrm{NSF}$

Penjelasan :

$\mathrm{N}=$ Nilai total dari kriteria

$\mathrm{NCF}=$ nilai rata-rata dari core factor

$\mathrm{NSF}=$ nilai rata-rata dari secondary factor

$(\mathrm{x}) \%=$ nilai dari persentase core factor serta secondary factor

Perhitungan Ranking

Langkah terakhir adalah menghitung nilai akhir tiaptiap karyawan menggunakan formula sebagai berikut (5)

$\mathrm{Ha}=(\mathrm{x}) \%$ Ntotal1 $+(\mathrm{x}) \%$ Ntotal $2+(\mathrm{x}) \%$ Ntotaln

Penjelasan :

$\mathrm{Ha}=$ Hasil Akhir nilai karyawan

NTotal1 $=$ total kriteria ke 1

NTotal2 $=$ total kriteria ke 2

NTotaln $=$ total kriteria ke $\mathrm{n}$

$(\mathrm{x}) \%=$ persentase nilai kriteria

\section{METODE PENELITIAN}

Metode penelitian yang digunakan pada penelitian ini adalah sebagai berikut :

1. Tahap pengumpulan data

Langkah pertama kali dalam penelitian ini adalah mengumpulkan data-data yang terkait dengan pemilihan karyawan yang berhak menerima bonus.

2. Tahap pengolahan data

Setelah mendapatkan data-data yang dibutuhkan maka proses selanjutnya yakni mengolah data. Data akan diolah menggunakan algoritma profile matching sehingga dapat diketahui bahwa algoritma profile matching cocok digunakan
3. Implementasi Sistem

Langkah berikutnya yakni mengimplementasikan algoritma profile matching kedalam bahasa pemrograman sehingga dihasilkan suatu sistem pendukung keputusan

4. Pengujian Sistem

Langkah terakhir adalah menguji aplikasi atau sistem pendukung keputusan yang telah berhasil dibangun. Aplikasi harus mampu memenuhi kebutuhan dari pihak pengambil keputusan.

\section{HASIL DAN PEMBAHASAN}

Untuk mendapatkan karyawan yang berhak mendapatkan bonus terhadap beberapa tahap diantaranya yaitu :

\section{A. Data Aspek}

Pada Data Aspek digunakan sebagai parameter penilaian karyawan yang hendak dipilih. Pada penelitian ini menggunakan data aspek sebanyak 2 aspek yaitu Aspek Kinerja dan Aspek Personality, kemudian tiap-tiap aspek akan diberikan nilai prosentase nilai. Dimana Nilai-nilai tersebut diperoleh dari pimpinan yang menentukan aspek-aspek manakah yang paling berpengaruh. Data Aspek dapat dilihat pada tabel 2 berikut:

Tabel 2 : Data Aspek

\begin{tabular}{|l|l|l|}
\hline Kode & Nama Aspek & Prosentase \\
\hline A01 & Aspek Kinerja & $60 \%$ \\
\hline A02 & Aspek Personality & $40 \%$ \\
\hline
\end{tabular}

Dari tabel 2 tersebut dapat terlihat aspek paling tinggi prosentasenya adalah adalah aspek Kinerja yaitu sebesar $60 \%$ sedangkan aspek Personality sebesar $40 \%$.

\section{B. Data Kriteria}

Data Kriteria adalah data yang berada pada aspek. Pada sebuah kriteria juga akan diberikan nilai standar yang diperoleh dari pimpinan pembuat keputusan. Dan pada kriteria juga terdapat jenis factor yaitu core dan secondary factor. Data kriteria terlihat pada tabel 3 .

Tabel 3 : Data Kiteria

\begin{tabular}{|l|l|l|l|l|l|}
\hline No & Kode & Aspek & $\begin{array}{l}\text { Nama } \\
\text { Kriteria }\end{array}$ & Nilai & Factor \\
\hline 1 & C01 & $\begin{array}{l}\text { Aspek } \\
\text { Kinerja }\end{array}$ & $\begin{array}{l}\text { Pencapaian } \\
\text { Target } \\
\text { pertahun }\end{array}$ & 4 & Core \\
\hline 2 & C02 & $\begin{array}{l}\text { Aspek } \\
\text { Kinerja }\end{array}$ & $\begin{array}{l}\text { Grow } \\
\text { Years }\end{array}$ & 4 & Secondary \\
\hline 3 & C03 & $\begin{array}{l}\text { Aspek } \\
\text { Kinerja }\end{array}$ & $\begin{array}{l}\text { Pendapatan } \\
\text { perbulan }\end{array}$ & 3 & Secondary \\
\hline 7 & C04 & $\begin{array}{l}\text { Aspek } \\
\text { Personality }\end{array}$ & $\begin{array}{l}\text { Komunikas } \\
\text { i }\end{array}$ & 4 & Core \\
\hline 8 & C05 & $\begin{array}{l}\text { Aspek } \\
\text { Personality }\end{array}$ & Disiplin & 4 & Secondary \\
\hline 9 & C06 & $\begin{array}{l}\text { Aspek } \\
\text { Personality }\end{array}$ & Team Work & 3 & Core \\
\hline 10 & C07 & $\begin{array}{l}\text { Aspek } \\
\text { Personality }\end{array}$ & $\begin{array}{l}\text { Responsibil } \\
\text { ity }\end{array}$ & 3 & Secondary \\
\hline
\end{tabular}




\section{Data Profile}

Data Profile adalah data mengenai penilaian dari suatu nilai aspek, pada sebuah profile berisi tentang penilaian yaitu

$1=$ Kurang

2 = Cukup

$3=$ Baik

4 = Sangat Baik.

\section{Data Karyawan}

Data Karyawan merupakan data karyawan yang akan dipilih untuk mendapatkan bonus akhir tahun. Data karyawan dapat dilihat pada tabel 4.

Tabel 4 : Data karyawan

\begin{tabular}{|l|l|l|l|}
\hline No & Kode & Nama Karyawan & Alamat \\
\hline 1 & K01 & Agus Pujianto & $\begin{array}{l}\text { Petukangan Utara, } \\
\text { ciledug }\end{array}$ \\
\hline 2 & K02 & Iko imanul H. & Banyu Biru, Labuan \\
\hline 3 & K03 & Rizky A. & $\begin{array}{l}\text { Pondok Pinang, } \\
\text { kebayoran }\end{array}$ \\
\hline 4 & K04 & Angga Saputra & Ciracas, Jaktim \\
\hline 5 & K05 & Fitra Ramadhan & $\begin{array}{l}\text { Margahayu Jaya, } \\
\text { Depok }\end{array}$ \\
\hline
\end{tabular}

\section{E. Data Nilai Karyawan}

Setelah diberikan penilaian dari petugas penilai maka didapatkan nilai seperti pada tabel 5 dan 6 .

Tabel 5 : Data nilai alternatif Aspek Kinerja

\begin{tabular}{|l|l|l|l|l|}
\hline \multirow{2}{*}{ Kode } & \multirow{2}{*}{$\begin{array}{l}\text { Nama } \\
\text { Karyawan }\end{array}$} & \multicolumn{3}{|c|}{ Aspek Kinerja } \\
\cline { 3 - 5 } & & $\begin{array}{l}\text { PTP } \\
(\mathrm{C} 01)\end{array}$ & $\begin{array}{l}\text { GY } \\
(\mathrm{C} 02)\end{array}$ & $\begin{array}{l}\text { PP } \\
(\mathrm{C} 03)\end{array}$ \\
\hline K01 & Agus Pujianto & 4 & 3 & 3 \\
\hline K02 & Iko imanul H. & 3 & 4 & 3 \\
\hline K03 & Rizky A. & 3 & 4 & 2 \\
\hline K04 & Angga Saputra & 2 & 3 & 3 \\
\hline K05 & Fitra Ramadhan & 3 & 4 & 2 \\
\hline
\end{tabular}

Keterangan :

PTP : Pencapaian Target Pertahun

GY : Grow Year

PP : Pendapatan Perbulan

Tabel 6 : Tabel data nilai alternatif Aspek Personality

\begin{tabular}{|l|l|l|l|l|l|}
\hline \multirow{2}{*}{ Kode } & \multirow{2}{*}{$\begin{array}{l}\text { Nama } \\
\text { Karyawan }\end{array}$} & $\begin{array}{l}\text { komun } \\
\text { ikasi } \\
(\mathrm{C} 04)\end{array}$ & $\begin{array}{l}\text { disiplin } \\
(\mathrm{C} 05)\end{array}$ & $\begin{array}{l}\text { Teamw } \\
\text { ork } \\
(\mathrm{C} 06)\end{array}$ & $\begin{array}{l}\text { responsib } \\
\text { ility } \\
(\mathrm{C} 07)\end{array}$ \\
\hline K01 & $\begin{array}{l}\text { Agus } \\
\text { Pujianto }\end{array}$ & 4 & 3 & 3 & 3 \\
\hline K02 & $\begin{array}{l}\text { Iko } \\
\text { imanul H. }\end{array}$ & 3 & 4 & 2 & 4 \\
\hline K03 & Rizky A. & 2 & 2 & 4 & 4 \\
\hline K04 & $\begin{array}{l}\text { Angga } \\
\text { Saputra }\end{array}$ & 2 & 3 & 2 & 3 \\
\hline K05 & $\begin{array}{l}\text { Fitra } \\
\text { Ramadhan }\end{array}$ & 2 & 3 & 3 & 2 \\
\hline
\end{tabular}

\section{F. Proses Pemetaan GAP}

Proses GAP diperoleh dari nilai yang diperoleh karyawan akan dibandingkan dengan dengan nilai standar dari pimpinan yang terlebih dahulu telah ditetapkan, sehingga didapatkan nilai GAP yang tampak pada tabel 7 dan 8
Tabel 7 : Pemetaan GAP Aspek Kinerja

\begin{tabular}{|l|l|l|l|}
\hline $\begin{array}{l}\text { Kode } \\
\text { Karyawan }\end{array}$ & C01 & C02 & C03 \\
\hline K01 & 4 & 3 & 3 \\
\hline K02 & 3 & 4 & 3 \\
\hline K03 & 3 & 4 & 2 \\
\hline K04 & 2 & 3 & 3 \\
\hline K05 & 3 & 4 & 2 \\
\hline $\begin{array}{l}\text { Nilai Standar } \\
\text { Kriteria }\end{array}$ & 4 & 4 & 3 \\
\hline K01 & 0 & -1 & 0 \\
\hline K02 & -1 & 0 & 0 \\
\hline K03 & -1 & 0 & -1 \\
\hline K04 & -2 & -1 & 0 \\
\hline K05 & -1 & 0 & -1 \\
\hline & & & \\
\hline
\end{tabular}

Tabel 8 : Pemetaan GAP Aspek Personality

\begin{tabular}{|l|l|l|l|l|}
\hline Kode karyawan & C06 & C07 & C08 & C09 \\
\hline K01 & 4 & 3 & 3 & 3 \\
\hline K02 & 3 & 4 & 2 & 4 \\
\hline K03 & 2 & 2 & 4 & 4 \\
\hline K04 & 2 & 3 & 2 & 3 \\
\hline K05 & 2 & 3 & 3 & 2 \\
\hline $\begin{array}{l}\text { Nilai Standar } \\
\text { Kriteria }\end{array}$ & 4 & 4 & 3 & 3 \\
\hline K01 & 0 & -1 & 0 & 0 \\
\hline K02 & -1 & 0 & -1 & 1 \\
\hline K03 & -2 & -2 & 1 & 1 \\
\hline K04 & -2 & -1 & -1 & 0 \\
\hline K05 & -2 & -1 & 0 & -1 \\
\hline
\end{tabular}

\section{G. Pembobotan Nilai GAP}

Setelah mendapatkan nilai perbandingan maka nilai tersebut dicocokan dengan tabel pembobotan GAP sehingga didapatkan hasil seperti pada tabel 9 .

\section{Tabel 9 : Pembobotan Nilai GAP}

\begin{tabular}{|c|c|c|c|c|}
\hline $\begin{array}{l}\text { Kode } \\
\text { Karyawan }\end{array}$ & $\mathrm{C} 01$ & $\mathrm{C} 02$ & $\mathrm{C} 03$ & \\
\hline K01 & 5 & 4 & 5 & \\
\hline K02 & 4 & 5 & 5 & \\
\hline K03 & 4 & 5 & 4 & \\
\hline K04 & 3 & 4 & 5 & \\
\hline K05 & 4 & 5 & 4 & \\
\hline & $\mathrm{C} 04$ & $\mathrm{C} 05$ & $\mathrm{C} 06$ & $\mathrm{C} 07$ \\
\hline K01 & 5 & 5 & 4 & 5 \\
\hline K02 & 4 & 4.5 & 3 & 4.5 \\
\hline K03 & 3 & 4 & 5 & 4.5 \\
\hline K04 & 3 & 5 & 3 & 5 \\
\hline K05 & 3 & 5 & 4 & 4 \\
\hline
\end{tabular}

\section{H. Pengelompokan Core dan Secondary Factor}

Setelah bobot nilai gap didapatkan atas masingmasing karyawan maka berikutnya yaitu menghitung nilai dari kelompok Core Factor serta Secondary Factor. Seperti yang terlihat pada tabel 10 dan 11

Tabel 10 : Core Factor dan secondary factor utuk Aspek Kinerja

\begin{tabular}{|c|c|c|c|c|c|}
\hline \multirow{2}{*}{$\begin{array}{l}\text { Kode } \\
\text { Karyawan }\end{array}$} & \multicolumn{3}{|c|}{ Aspek Kinerja } & \multirow[t]{2}{*}{$\mathrm{CF}$} & \multirow[t]{2}{*}{ SF } \\
\hline & $\mathrm{C} 01$ & $\mathrm{C} 02$ & $\mathrm{C03}$ & & \\
\hline K01 & 5 & 4 & 5 & 3.000 & 2.700 \\
\hline K02 & 4 & 5 & 5 & 2.400 & 3.000 \\
\hline K03 & 4 & 5 & 4 & 2.400 & 2.700 \\
\hline K04 & 3 & 4 & 5 & 1.800 & 2.700 \\
\hline K05 & 4 & 5 & 4 & 2.400 & 2.700 \\
\hline
\end{tabular}


Tabel 11 : core dan secondary factor Aspek Personality

\begin{tabular}{|c|c|c|c|c|c|c|}
\hline \multirow{2}{*}{$\begin{array}{l}\text { Kode } \\
\text { Karyawan }\end{array}$} & \multicolumn{4}{|c|}{ Aspek Personality } & \multirow[t]{2}{*}{$\mathrm{CF}$} & \multirow[t]{2}{*}{$\mathrm{SF}$} \\
\hline & $\mathrm{C} 06$ & $\mathrm{C} 07$ & $\mathrm{C} 08$ & $\mathrm{C} 09$ & & \\
\hline K01 & 5 & 5 & 4 & 5 & 1.800 & 2.000 \\
\hline K02 & 4 & 4.5 & 3 & 4.5 & 1.400 & 1.800 \\
\hline K03 & 3 & 4 & 5 & 4.5 & 1.600 & 1.700 \\
\hline K04 & 3 & 5 & 3 & 5 & 1.200 & 2.000 \\
\hline K05 & 3 & 5 & 4 & 4 & 1.400 & 1.800 \\
\hline
\end{tabular}

\section{Perhitungan total nilai}

Setelah mendapatkab nilai core factor serta secondary factor maka langkah berikutnya yaitu menghitung total nilai dari core serta secondary factor dengan ketentuan yakni : $\mathrm{N} 1=(60 \% \mathrm{X} \mathrm{NCF})+(40 \%$ $\mathrm{X}$ NSF). Sehingga didapatkan nilai yang dapat dilihat pada tabel 12 dan 13 :

Tabel 12 : Total nilai aspek kinerja

\begin{tabular}{|l|l|l|l|}
\hline Kode Karyawan & CF & SF & N1 \\
\hline K01 & 3.000 & 2.700 & 5.700 \\
\hline K02 & 2.400 & 3.000 & 5.400 \\
\hline K03 & 2.400 & 2.700 & 5.100 \\
\hline K04 & 1.800 & 2.700 & 4.500 \\
\hline K05 & 2.400 & 2.700 & 5.100 \\
\hline
\end{tabular}

Tabel 13 : Total nilai aspek personality

\begin{tabular}{|l|l|l|l|}
\hline Kode Karyawan & \multicolumn{1}{|c|}{ CF } & SF & N2 \\
\hline K01 & 1.800 & 2.000 & 3.800 \\
\hline K02 & 1.400 & 1.800 & 3.200 \\
\hline K03 & 1.600 & 1.700 & 3.300 \\
\hline K04 & 1.200 & 2.000 & 3.200 \\
\hline K05 & 1.400 & 1.800 & 3.200 \\
\hline
\end{tabular}

\section{J. Perhitungan Nilai Rangking}

Untuk mencari nilai dari perangkingan maka menggunakan ketentuan : $(60 \%$ X N1) + $(40 \%$ X N2) sehingga didapatkan nilai seperti pada tabel 14.

Tabel 14 : Perhitungan nilai rank

\begin{tabular}{|l|l|l|l|l|}
\hline & N1 & N2 & Total & Rank \\
\hline K01 & 5.700 & 3.800 & 4.94 & 1 \\
\hline K02 & 5.400 & 3.200 & 4.52 & 2 \\
\hline K03 & 5.100 & 3.300 & 4.38 & 3 \\
\hline K04 & 4.500 & 3.200 & 3.98 & 5 \\
\hline K05 & 5.100 & 3.200 & 4.34 & 4 \\
\hline
\end{tabular}

Berdasarkan tabel 14 maka terlihat karyawan yang mendapatkan nilai total tertinggi adalah karyawan dengan kode K01 atas nama Agus Pujianto dengan perolehan nilai total sebesar 4.94 dan karyawan yang mendapatkan nilai terkecil adalah karyawan dengan kode K04 atas nama Angga Saputra dengan perolehan nilai 3.98. sehingga karyawan dengan nama Agus Pujiantolah yang berhak mendapatkan bonus akhir tahun dari perusahaan berdasarkan keluaran sistem.

\section{K. Tampilan Sistem Pendukung Keputusan}

Berikut adalah contoh perhitungan dari sistem pendukung keputusan yang telah selesai dibangun :

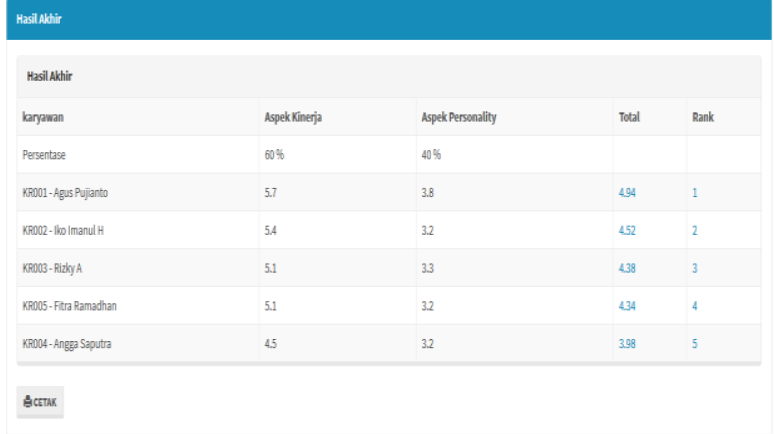

Gambar 2 : Tampilan Hasil Perhitungan

Berdasarkan gambar 2 diatas dapat terlihat bahwa karyawan yang menduduki peringkat pertama adalah agus pujianto dengan total nilai 4.94. hal ini menunjukan bahwa algoritma profile matching telah berhasil dengan baik dan dapat diimplementasikan kedalam sebuah sistem pendukung keputusan.

\section{KESIMPULAN}

Berdasarkan penelitian yang telah dilakukan, algoritma yang telah diimplementasikan serta diujikan, maka dapat ditarik kesimpulan sebagai berikut :

1. Sistem pendukung keputusan pemilihan karyawan yang berhak mendapatkan bonus pada akhir tahun yang telah selesai dibangun dapat memberikan masukan kepada pimpinan mengenai karyawan yang berhak mendapakannya.

2. Hasil penelitian menunjukan bahwa karyawan yang mendapatkan nilai tertinggi sebesar 4.94 dikuti dengan 4.52, 4.38, 4.34 hingga yang terkecil 3.98.

3. Dalam penelitian selanjutnya dapat memadukan algoritma AHP untuk pembobotan kriteria dan perhitungannya menggunakan profile matching.

\section{DAFTAR PUSTAKA}

[1] M. Astradanta, I. M. A. Wirawan, and I. K. R. Arthana, "Pengembangan Sistem Penunjang Keputusan Pemilihan Tempat Kuliner Dengan Menggunakan Metode AHP Dan SAW Studi Kasus: Kecamatan Buleleng," Kumpul. Artik. Mhs. Pendidik. Tek. Inform. (KARMAPATI, vol. 5, pp. 2252-9063, 2016.

[2] M. M. Amin and E. Cofriyanti, "Sistem Rekomendasi Pemilihan Kandidat Calon Tenaga Kerja Menggunakan Model Profile Matching," Pros. SINTAK, pp. 108-115, 2017.

[3] D. Fitriani, "Sistem Pendukung Keputusan Penentuan Karyawan Terbaik Pada Collection Pt . Panin Bank Menggunakan,” J. Mantik Penusa, vol. 3, no. 1, pp. 1-8, 2019.

[4] B. B. Mulia Sulistiyono, "Implementasi Sistem 
Pendukung Keputusan Seleksi Penerimaan Karyawan Baru Dengan Metode Profile Matching," Respati, vol. 13, no. 3, pp. 71-78, 2018.

[5] L. T. Adin Setiawan, Sutardi, "Spk Penilaian Dan Pemberian Bonus Salesman Pada Pt Matakar Kendari Dengan Menggunakan Metode Profile Matching," SemanTIK, vol. 3, no. 1, pp. 199208, 2017.

[6] N. Aeni Hidayah and E. Fetrina, "Rancang Bangun Sistem Pendukung Keputusan Kenaikan Jabatan Pegawai Dengan Metode Profile Matching (Studi Kasus: Kementerian Agama Kantor Wilayah DKI Jakarta)," Stud. Inform. J. Sist. Inf., vol. 10, no. 2, pp. 127-134, 2017.

[7] F. A. Sianturi, "Implementasi Sistem Pendukung Keputusan Kenaikan Jabatan Guru Dengan Model Profile Matching Pada Sekolah Sma Swasta Raksana Medan," Mantik Penusa, vol. 18, no. 2, pp. 44-52, 2015.

[8] Budi Sudrajat, "Pemilihan Pegawai Berprestasi Dengan Menggunakan Metode Profile Matching," J. Inf. Syst. Applied, Manag. Account. Res., vol. 2, no. 4, pp. 20-28, 2018.

[9] N. S. Mujito, Basuki Hari Prasetyo, "Implementasi Algoritme Profile Matching Untuk Perekrutan Karyawan," J. RESTI (Rekayasa Sist. dan Teknol. Informasi), vol. 1, no. 1, pp. 190-195, 2019. 